\title{
Prymazy prokariotyczne - budowa i funkcje
}

\section{STRESZCZENIE}

$\mathbf{P}$ ymazy odpowiadają za syntezę krótkich oligo RNA, które służą jako startery do syntezy prowadzonej przez polimerazy DNA. Prymazy odgrywają kluczową rolę $w$ inicjacji syntezy nici DNA w miejscach początku replikacji (ang. replication origin), syntezie fragmentów Okazaki oraz ponownym uruchomieniu zatrzymanych widełek replikacyjnych. Prokariotyczne prymazy na podstawie budowy i porównania sekwencji aminokwasowych zaliczane są do rodziny białek DnaG. Prymazy należące do tej rodziny posiadają trzy odrębne domeny. Na N-końcu znajduje się domena wiążąca cynk odpowiedzialna za wiązanie matrycowego DNA. Środkowa domena odpowiedzialna jest za aktywność polimerazy RNA natomiast C-końcowa domena posiada aktywność helikazy lub odpowiada za oddziaływanie z helikazą. Poniżej przedstawiamy porównanie mechanizmu działania prymaz rodziny DnaG, a także ich udział w syntezie DNA w widełkach replikacyjnych.

\section{WPROWADZENIE}

Prawidłowy przebieg replikacji DNA ma fundamentalny wpływ na utrzymanie stabilności materiału genetycznego, a co za tym idzie na prawidłowe funkcjonowanie komórek czy organizmów. Mechanizmy replikacji DNA oraz funkcjonalne komponenty wchodzące w skład złożonej maszynerii replikacji DNA są zachowane w ewolucji. Niezależnie od badanego organizmu, podczas replikacji DNA, można wyróżnić istotne wspólne cechy takie jak: (1) zdefiniowane miejsca inicjacji replikacji (ang. replication origin), (2) dwukierunkowość replikacji przy udziale polimeraz DNA (nić wiodąca i opóźniona), (3) synteza starterów RNA przez prymazę, (4) ciągła synteza DNA na nici wiodącej, (5) synteza DNA w postaci fragmentów Okazaki na nici opóźnionej, (6) rozplatanie dwuniciowego DNA przez helikazy. Syntezę DNA na obu niciach, wiodącej i opóźnionej, koordynuje wielobiałkowy kompleks, zwany replisomem. Głównymi białkami wchodzącymi w skład replisomu są helikazy, prymazy i polimerazy DNA odpowiedzialne za jednoczesną replikację obu nici DNA.

Jednym z większych wyzwań dla komórki jest równoczesna synteza dwóch nici DNA o przeciwnej polarności, ponieważ polimeraza DNA działa jednokierunkowo, wstawiając deoksyrybonukleotydy tylko w kierunku 5' $\rightarrow 3^{\prime}$. Replikacyjne polimerazy DNA nie są w stanie inicjować replikacji na jednoniciowym DNA (ssDNA) i mogą wydłużać tylko istniejące już statery, które mają wolną grupę 3’OH. Prymazy, które są DNA zależnymi RNA polimerazami, posiadają zdolność syntetyzowania de novo krótkich starterów RNA, dlatego też odgrywają kluczową rolę w inicjacji syntezy nici DNA w miejscach początku replikacji, inicjowaniu fragmentów Okazaki oraz ponownym uruchomieniu zatrzymanych widełek replikacyjnych [1,2].

Prymazy nie stanowią jednolitej grupy. W oparciu o sekwencję i dane strukturalne, prymazy DNA zostały podzielone na dwie grupy: prymazy prokariotyczne oraz archeo-eukariotyczne. Wszystkie prymazy mają podobne właściwości, ale białka w tych dwóch klasach różnią się zarówno ze względu na strukturę jak i oddziaływania z innymi białkami w kompleksie replikacyjnym. Priokariotyczne prymazy zwykle są związane z helikazą DNA, podczas gdy eukariotyczne prymazy występują w kompleksach z polimerazą DNA- $a(\operatorname{Pol} \propto)$ [1,3].

W pracy przedstawiamy budowę i funkcje prymaz prokariotycznych. O budowie i roli prymaz eukariotycznych w replikacji czytelnik znajdzie wiadomości $\mathrm{w}$ pracach przeglądowych $[4,5]$.

\section{PRYMAZY PROKARIOTYCZNE - BUDOWA I FUNKCJE}

Większość prymaz bakteriofagowych i bakteryjnych zbudowana jest z jednej podjednostki [1]. Enzymy te potrafią wiązać jednoniciowe DNA, a następnie z

\section{Izabela Ziuzia-Graczyk ${ }^{1}$}

\section{Anna Bębenek ${ }^{2, \varpi}$}

${ }^{1}$ Zakład Biologii Molekularnej, Instytut Biochemii i Biofizyki, Polska Akademia Nauk, Warszawa

${ }^{2}$ Pracownia Mutagenezy i Reperacji DNA, Instytut Biochemii i Biofizyki, Polska

Akademia Nauk, Warszawa

$\triangle_{\text {Pracownia }}$ Mutagenezy i Reperacji DNA, Instytut Biochemii i Biofizyki, Polska Akademia Nauk, ul. Pawińskiego 5a, 02-106 Warszawa; tel.: (22) 59211 25, e-mail: aniab@ ibb.waw.pl

Artykuł otrzymano 25 października $2018 \mathrm{r}$. Artykuł zaakceptowano 8 stycznia 2019 r.

https://doi.org/10.18388/pb.2019_253

Słowa kluczowe: prymaza, polimeraza RNA, domena Toprim; helikaza, SSB, widełki replikacyjne

Wykaz skrótów: DnaB - helikaza DnaB; DnaG - prymaza DnaG; dsDNA - dwuniciowe DNA; FRET (ang. Förster Resonance Energy Transfer) - mechanizm przenoszenia energii między dwoma chromoforami na drodze innej niż promieniowanie; gp2.5 - białka wiążące jednoniciowe DNA faga T7; gp45 - czynnik procesywności bakteriofaga T4; ZBD (ang. Zinc Binding Domain) - domena wiążąca cynk; RPD (ang. RNA Polimerase Domain) - domena polimerazy RNA; SAXS (ang. Small-angle X-ray scattering) rozpraszanie promieniowania rentgenowskiego pod małymi kątami; ssDNA - jednoniciowe DNA; SSB (ang. single stranded DNA binding proteins) - prokariotyczne białka wiążące się z jednoniciowym DNA 
wykorzystaniem rybonukleotydów tworzyć krótki starter RNA. Szybkość, z jaką prymaza syntetyzuje starter jest niezwykle niska. Aktywność prymaz stymulowana jest w obecności helikaz replikacyjnych [6,7]. Niektóre prymazy, tak jak te z fagów T7, T3 oraz P4, występują w postaci dwufunkcyjnego białka posiadającego zarówno aktywność prymazy jak i helikazy [2,7-9].

Wszystkie znane bakteryjne prymazy, a także prymazy z wielu bakteriofagów zostały zakwalifikowane do rodziny prymaz DnaG, ponieważ wykazują duży stopień homologii do prymazy DnaG z Escherichia coli. Porównanie sekwencji reszt aminokwasowych dla jedno i dwufunkcyjnych prymaz pozwoliło na wyodrębnienie trzech domen z wyróżniającymi się sześcioma zachowanymi w ewolucji motywami sekwencji. N-końcowa domena posiada pojedynczy motyw wiążący cynk (ZBD, ang. zinc-binding domain), który jest niezbędny do rozpoznawania specyficznej sekwencji w DNA. Centralna domena, domena polimerazy RNA (RPD, ang. RNA polymerase domain), obejmujacca motywy II-VI, zawiera miejsce aktywne odpowiedzialne za syntezę oligorybonukleotydów. C-końcowa domena nie jest zachowana w ewolucji i posiada region odpowiedzialny za oddziaływanie $\mathrm{z}$ helikazą albo, jak w przypadku dwufunkcyjnych prymaz, aktywność helikazy [1,10-12].

\section{DOMENA WIĄŻĄCA CYNK}

Analiza sekwencji aminokwasowej prymaz wykazała obecność motywu wiążącego cynk, który znajduje się w prymazach zarówno prokariotycznych jak i eukariotycznych. Wszystkie prymazy DNA, które posiadają miejsce wiążące metal (cynk) zbudowane są z czterech konserwowanych reszt cystein $\left(\mathrm{Cys}_{4}\right)$ lub cystein i histydyn [13]. W prymazach prokariotycznych miejsce wiążące metal znajduje się na N-końcu polipeptydu $[13,14]$. Struktura krystalograficzna domeny ZBD z Bacillus stearothermophilus pokazała, że domena ta przyjmuje strukturę opisywaną jako wstążka cynkowa (ang. zinc ribbon) i zbudowana jest głównie z 5 antyrównoległych kartek $\beta$ i otaczających ją czterech a-helis [14]. Domena ZBD bakteriofaga T7 jest mniejsza, zbudowana z 4 antyrównoległych $\beta$ kartek i jednej helisy a [15]. Obie domeny wiążą jeden atom cynku. Podobne domeny występują w większości białek uczestniczących w procesie transkrypcji i translacji, jak np.: w czynniku inicjacji transkrypcji (TFIIB), transkrypcyjnym czynniku elongacji SII (TfIIS), a także w polimerazach RNA, topoizomerazach czy białkach rybosomalnych [16].

Domena ZBD jest niezbędna dla pełnej aktywności prymazy. Jednak pomimo informacji strukturalnych otrzymanych dla kilku różnych prymaz, dokładna rola motywu wiążącego cynk w syntezie startera pozostaje niejasna. Prymazy bakteryjne i bakteriofagowe katalizują zależną od matrycy syntezę oligorybonukleotydów ze specyficznych sekwencji DNA $[15,17,18]$. W celu zbadania roli palców cynkowych $\mathrm{w}$ rozpoznawaniu specyficznych sekwencji i interakcji z matrycą DNA analizie poddano szereg mutantów prymazy T7, zawierających różne podstawienia aminokwasowe w pobliżu reszt koordynujących cynk. Wyniki tych badań wskazują, że motyw wiążący cynk sam nie jest odpowiedzialny za rozpoznanie sekwencji, a dopiero jego oddziaływanie z do- meną polimerazy RNA (RPD) jest istotne dla wiązania DNA i rozpoznawanie specyficznych sekwencji $[17,19]$. Pokazano również, że podstawienie reszty seryny dla którejkolwiek $\mathrm{z}$ czterech zachowanych $\mathrm{w}$ ewolucji reszt cysteinowych $\mathrm{w}$ motywie cynkowym prymazy T7 oraz mutacja reszty His33 do reszty Ala hamuje syntezę startera ze specyficznie rozpoznawanych miejsc w sekwencji DNA, natomiast prymaza może syntetyzować dinukleotydy z przypadkowych sekwencji $[1,13,17]$.

\section{DOMENA KATALITYCZNA PRYMAZY}

Domena ta znajduje się za domeną ZBD i połączona jest $\mathrm{z}$ nią krótkim, elastycznym białkowym łącznikiem. Struktura dla katalitycznej domeny prymazy, około 320 reszt aminokwasowych (reszty 111-433) DnaG z E. coli została rozwiązana przez dwie grupy, Keck i wsp. oraz Podobnik i wsp. $[20,21]$, a jej kształt określono, jako podobny do orzecha nerkowca [20] lub półksiężyca [21].

W domenie katalitycznej prymaz rodziny DnaG można wyróżnić trzy subdomeny: N-końcową (złożoną z czterech antyrównoległych $\beta$-kartek i kilku helis), centralną (posiadającą strukturę podobną do struktury domeny TOPRIM, która występuje również $\mathrm{w}$ domenach katalitycznych topoizomeraz oraz niektórych nukleaz i białek rekombinacyjnych) oraz C-końcową domenę. Centralna domena (reszty 259-341) zawiera miejsce aktywne i odpowiedzialna jest za przyłączanie nukleotydów [22,23].

W domenie RPD można wyróżnić pięć zachowanych w ewolucji motywów II-VI. Motywy II i III znajdują się w N-końcowej subdomenie. Rola motywu II nie jest poznana, natomiast zbudowany $\mathrm{z}$ zasadowych reszt aminokwasowych o sekwencji zachowanej w ewolucji region prymazy w pobliżu motywu III występuje także w kilku dużych podjednostkach zarówno prokariotycznych jak i eukariotycznych polimeraz RNA i odgrywa istotną rolę w syntezie RNA. Dla prymazy DnaG z Escherichia coli w rejonie tego motywu wykazano obecność mającego ważne znaczenie rowka wiążącego ssDNA [18]. Rowek ten znajduje się na powierzchni prymazy, umożliwiając jej przechwytywanie i przesuwanie się na dopiero co powstałym ssDNA wychodzącym z helikazy. Istotną rolę w oddziaływaniu z ssDNA w tym rejonie odgrywają Trp165, Arg199 i Arg201 [18]. Mutacje, którejkolwiek z tych reszt aminokwasowych do Ala w znaczny sposób hamują aktywność prymazy DnaG [18]. Wykazano również, że w prymazie DnaG w tym regionie ważną rolę odgrywa reszta Lys-241 (jako niezbędna część centrum katalitycznego jest istotna dla wydłużania dinukleotydów), której w prymazie faga T7 odpowiadają Lizyny 122 i $128[24,25]$.

W centralnej subdomenie występuje wiele reszt aminokwasowych obejmujących motywy IV-VI, które są niezbędne dla wiązania nukleotydu oraz syntezy oligorybonukleotydów. Każdy z motywów IV, V lub VI jest zaangażowany w koordynację wiązania substratów NTP i dwuwartościowych kationów metali niezbędnych dla katalizy. Godson i wsp. [26] zlokalizowali reszty aminokwasowe zaangażowane w wiązanie jonów metali w prymazie E. coli. Jeden z ważnych asparaginianów (D269) znajduje się w sekwencji 

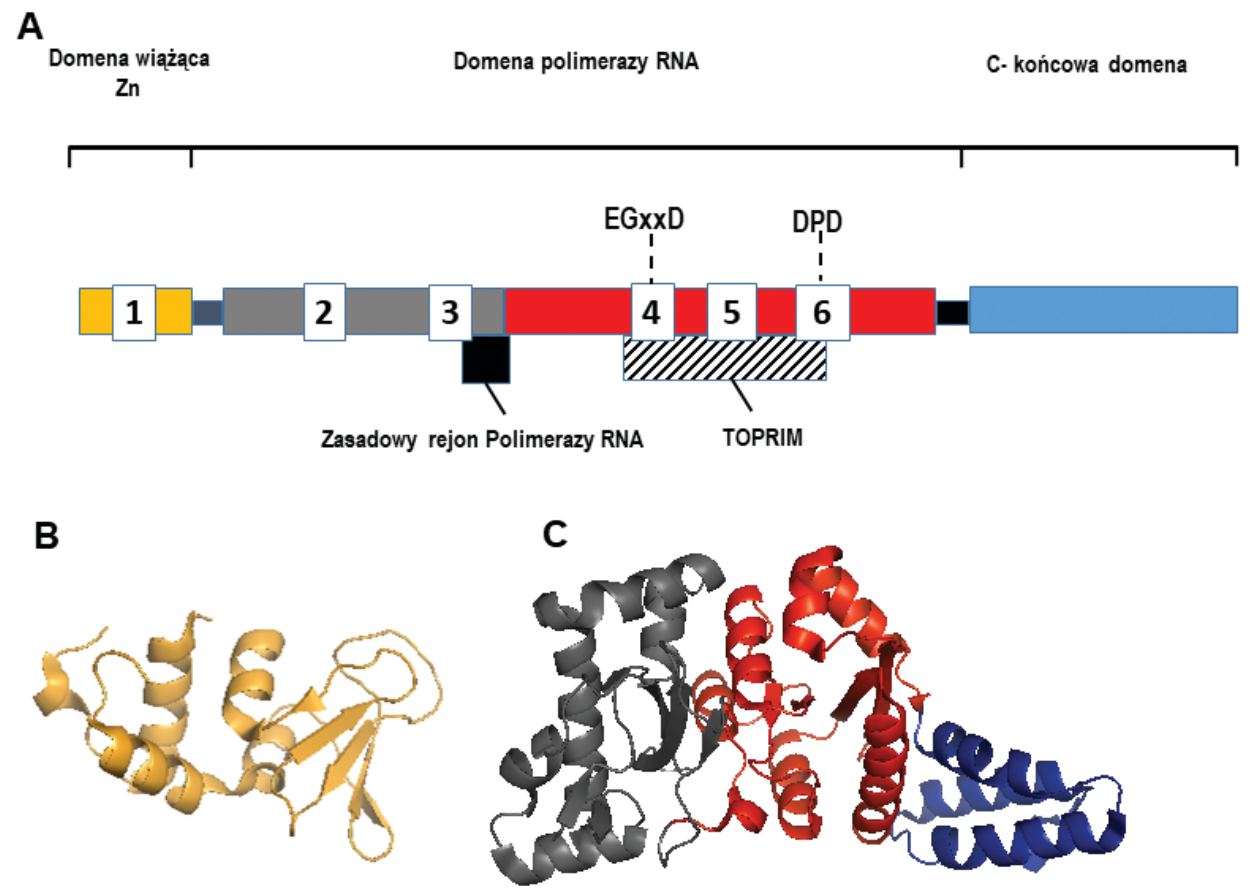

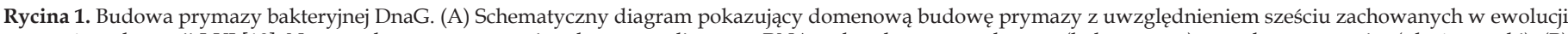

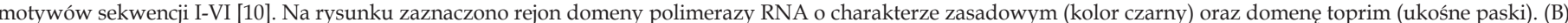

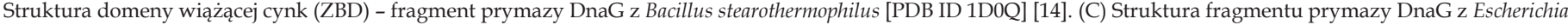

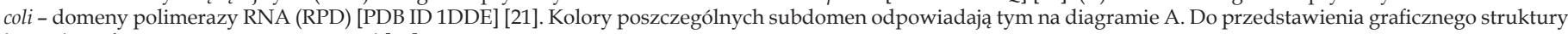
krystalograficznej użyto program Pymol [75].

Glu-Gly-Tyr-Met-Asp (EGYMD) motywu IV. Motyw ten jest zachowany we wszystkich bakteryjnych prokariotycznych prymazach oraz w prymazach fagowych, jako motyw EGxxD (z wyjątkiem prymazy faga P4) [26]. Inne koordynujące jony metali asparaginiany Asp345 i Asp347 znajdują się w sekwencji Asp-Pro-Asp (DPD) zlokalizowanej w motywie VI. Sekwencja DPD jest zachowana w ewolucji we wszystkich prymazach bakteryjnych podobnych do bakteryjnego białka DnaG, ale jedynie pierwszy asparaginian $\mathrm{w}$ tej sekwencji jest obecny w prymazach fagowych $[1,26]$. Również istotny dla aktywności prymazy jest zachowana w ewolucji w motywie EGxxD reszta kwasu glutaminowego (E265 w prymazie DnaG z E. coli), ponieważ jego zamiana do glutaminy $(\mathrm{Q})$ hamuje aktywność katalityczną prymazy. Rola tego aminokwasu nie jest do końca jasna [26].

\section{DOMENA C-KOŃCOWA PRYMAZY}

C-końcowa domena (CTD, ang. C-terminal domain) nie występuje w prymazie T7, ponieważ prymaza ta jest kowalencyjnie związana z helikazą i tworzy dwufunkcyjne białko [11]. W bakteryjnych prymazach, podobnie jak $\mathrm{w}$ prymazie faga T4, C-końcowa domena, zwana C-końcową domeną interakcji (ang. C-terminal interaction domain) lub domeną wiążąca helikazę (HBD, ang. helicase binding domain) odpowiada za oddziaływanie z helikazą (poprzez osiem ostatnich reszt aminokwasowych [27]), stymulację aktywności enzymatycznej helikazy, a także umiejscowienie enzymu w widełkach replikacyjnych $[1,14,20]$.

Wykazano, że prymaza DnaG z E. coli zawierająca substytucję jednej reszty aminokwasowej na C-końcu (Q576A) wiąże helikazę DnaB ze znacznie niższym powinowactwem niż białko typu dzikiego [28]. Inne mutacje zlokalizowane na C-końcu białka DnaG również mogą wpływać na koordynację prymazy w procesie replikacji [1].

Ponadto C-końcowa domena wiążąca helikazę prymazy DnaG bierze też udział w oddziaływaniu z C-końcowym heksapeptydem (DDDIPF) białka wiążącego jednoniciowe DNA, SSB, o sekwencji zachowanej w ewolucji [29].

W strukturze krystalograficznej prymazy DnaG z E. coli domena ta zbudowana jest z trzech antyrównoległych wiązek a-helis [21]. W obrębie prymaz struktura C-końcowej domeny nie jest zachowana w ewolucji. Budowa i struktura prymaz rodziny DnaG przedstawiona jest na rycinie 1.

\section{KOMPLEKS PRYMAZA - HELIKAZA - PRYMOSOM}

Prymazy występują razem z helikazami replikacyjnymi tworząc prymosom. Wiązanie prymazy i helikazy bardzo stymuluje zarówno aktywność prymazy jak i helikazy [3032]. Helikaza DnaB w swojej aktywnej formie tworzy homoheksameryczny pierścień. Każda z podjednostek posiada dwie domeny, N-końcową (NTD) i C-końcową domenę (CTD), w której znajduje się miejsce wiązania ATP i DNA. Domena CTD ma budowę podobną do ATPazowej domeny białka RecA [29]. Obie domeny połączone są łącznikiem zbudowanym z dwóch ułożonych antyrównolegle a-helis, które tworzą strukturę szpilki [32,33]. Łącznik ten pełni istotną funkcję w czasie oligomeryzacji helikazy DnaB [33]. W komórkach Escherichia coli helikaza DnaB jest ładowana na DNA w miejscu inicjacji replikacji przez białko DnaC. Po załadowaniu helikazy białko DnaC oddysocjowuje, a helikaza, która związana jest z jedną nicią DNA rozplata 


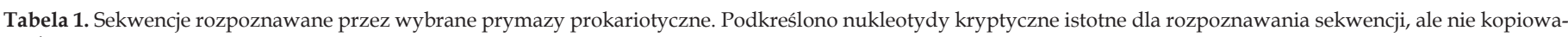
ne do powstającego startera.

\begin{tabular}{|c|c|c|c|}
\hline Prymaza & Sekwencja rozpoznawana & Długość startera syntetyzowana przez prymosom & Piśmiennictwo \\
\hline DnaG z E. coli & $\begin{array}{l}5^{\prime} \mathrm{d}(\mathrm{CT} \underline{\mathrm{G}}) \\
5^{\prime} \mathrm{d}(\mathrm{CA} \underline{\mathrm{G}})\end{array}$ & $8-12 \mathrm{nt}$ & {$[21]$} \\
\hline DnaG z B. subtilis & $\begin{array}{l}5^{\prime} \mathrm{d}(\mathrm{GT} \underline{\mathrm{A}}) \\
5^{\prime} \mathrm{d}(\mathrm{TT} \underline{\mathrm{A}}) \\
5^{\prime} \mathrm{d}(\mathrm{TT} \underline{\mathrm{T}})\end{array}$ & $2-4 \mathrm{nt}$ & {$[74]$} \\
\hline Gp61 z T4 & $\begin{array}{l}5^{\prime} \mathrm{d}(\mathrm{GTT}) \\
5^{\prime} \mathrm{d}(\mathrm{GC} \underline{\mathrm{T}})\end{array}$ & $5 \mathrm{nt}$ & [45] \\
\hline Gp4 z T7 & $\begin{array}{l}5^{\prime} \mathrm{d}(\mathrm{GTC}) \\
5^{\prime} \mathrm{d}(\mathrm{GTT})\end{array}$ & $4 \mathrm{nt}$ & {$[13]$} \\
\hline
\end{tabular}

podwójną helisę w kierunku 5'-3' wykorzystując do tego hydrolizę ATP [34]. ssDNA, które wychodzi z pierścienia helikazy służy prymazie jako matryca do syntezy starterów dla fragmentów Okazaki nici opóźnionej. Występowanie helikazy i prymazy w kompleksie pozwala na łatwe przeszukiwanie ssDNA przez prymazę $\mathrm{w}$ poszukiwaniu miejsc inicjacji starterów. Rekrutacja prymazy DnaG do helikazy DnaB w widełkach replikacyjnych reguluje aktywność syntetyzowania starterów przez prymazę i odwrotnie, prymaza stymuluje aktywność ATPazową helikazy. Podobne zależności istnieją $\mathrm{w}$ innych systemach replikacyjnych faga T7 i T4 $[28,35,36]$.

Wiązanie prymazy i helikazy odbywa się od strony Ckońcowej prymazy i N-końcowej helikazy. Stechiometria kompleksu prymazy DnaG i helikazy DnaB z E. coli została określona na 2-3 cząsteczki prymazy na jeden heksamer helikazy $[6,31,32]$. Oddziaływania helikazy i prymazy w komórkach $E$. coli są słabe i przejściowe $[6,28]$. Te same białka tworzą stabilne kompleksy w komórkach Bacillus stearothermophilus [31]. W systemie replikacyjnym bakteriofaga T7 produkt genu gp4 stanowi białko, w którym N-końcowa domena posiada aktywność prymazy, a C-końcowa aktywność helikazy. W pełni funkcjonalne białko ma wielkość 63 kDa. Fag T7 syntetyzuje również skróconą formę białka gp4 o wielkości 56 kDa, która nie posiada N- końcowej domeny ZBD prymazy. Ta skrócona wersja nie jest $\mathrm{w}$ stanie katalizować zależnej od matrycy syntezy starterów, ale może oligomeryzować i ma w pełni zachowaną aktywność helikazy [1,12]. Domena helikazy białka gp4 potrzebuje dla swojej aktywności obecności dTTP, którego hydroliza dostarcza energii do translokacji na ssDNA i rozplatania dsDNA [37]. Forma długa i krótka są syntetyzowane przez faga w takich samych ilościach [38]. Wykazano, że białko gp4 o pełnej długości jak również forma skrócona mogą tworzyć mieszane heksamery. Rola skróconej formy białka gp4 nie jest wyjaśniona. Dla faga T7, gdzie prymaza i helikaza tworzą dwufunkcyjne białko heksamer gp4 jest enzymatycznie aktywną formą [8]. W układzie replikacyjnym faga T4 stechiometria białek tworzących prymosom, prymazy gp61 i helikazy gp41, nie jest do końca poznana. Badania grupy Benkovica pokazały, że funkcjonalny prymosom faga T4 zbudowany jest z heksamerycznej helikazy gp41 i związanych z nią sześciu cząsteczek białka prymazy gp61. Stechiometria 1:6 wskazuje, że heksamer helikazy wiąże 6 cząsteczek prymazy, co sugeruje, że aktywna prymaza, podobnie jak helikaza może przyjmować strukturę pierścienia [39]. Inne badania z grupy von Hippel'a pokazały, że tylko jedna cząsteczka prymazy wiąże się z pierścieniem helikazy, a stechiometria wynosi 1:1 [40].

\section{SYNTEZA STARTERA}

W syntezie starterów można wyróżnić pięć etapów: (1) rozpoznanie matrycy, (2) wiązanie nukleotydu, (3) inicjację syntezy, (4) wydłużenie do funkcjonalnego startera oraz (5) dostarczenie startera do polimerazy DNA.

Miejsce inicjacji syntezy startera znajduje się w ściśle zdefiniowanej sekwencji matrycy DNA. Na ogół prymazy rozpoznają trinukleotydwe sekwencje (ang. priming sites). Pomimo zbliżonej budowy, każda z opisanych do tej pory prymaz rozpoznaje swoją własną sekwencję. Sekwencje rozpoznawane przez znane prymazy zamieszczono w tabeli 1 . W każdej z rozpoznawanych trinukleotydowych sekwencji pierwszy nukleotyd jest istotny dla rozpoznania danej sekwencji, ale nie jest kopiowany do powstającego startera (nukleotyd kryptyczny) [1].

W centrum katalitycznym prymazy można wyróżnić dwa miejsca, w których wiązane są nukleotydy, miejsce inicjacji i miejsce elongacji. Domena ZBD odgrywa istotną rolę w stabilizacji kompleksu prymazy i DNA poprzez oddziaływanie z domeną RPD.

W oparciu o strukturę krystalograficzną prymazy T7, analizę NMR i dane biochemiczne zaproponowano model, w którym domeny ZBD i RPD oddzielone od siebie długim łącznikiem nie oddziałują ze sobą $\mathrm{w}$ nieobecności substratów (otwarta konformacja prymazy). Podczas syntezy startera prymaza podlega konformacyjnej zmianie $\mathrm{w}$ regionie łącznika, co powoduje, że domeny ZBD oraz RPD nawiązują kontakt z matrycą i nukleotydowymi substratami (zamknięta konformacja prymazy) [11,41].

Prymaza T7 napotykając odpowiednie miejsce inicjacji, 5'-GTC-3' katalizuje syntezę dirybonukleotydów pppAC używając ATP i CTP, tzw. kondensacja nukleotydów. Po syntezie dirybonukleotydu domena ZBD ciągle związana $\mathrm{z}$ dinukleotydem i matrycą przesuwa się $\mathrm{w}$ kierunku centrum katalitycznego domeny RPD przybliżając kolejne nukleotydy matrycy do centrum aktywnego prymazy, co umożliwia wydłużanie pppAC do funkcjonalnych te- 
trarybonukleotydowych starterów pppACCC, pppACAC lub pppACCA zależnie od sekwencji matrycy $[1,11,42]$. Startery syntetyzowane de novo muszą być stabilizowane przez prymazę, a następnie przekazywane polimerazie DNA do inicjacji syntezy DNA [1,12]. Kryptyczna reszta cytozyny nie jest kopiowana do startera, ale pełni ważną rolę w stabilizacji kompleksu prymazy i DNA [43]. Mutacje w domenie ZBD zaburzają rozpoznawanie trinukleotydowch sekwencji w DNA [44]. Zaobserwowano jednak, że prymaza pozbawiona domeny ZBD była w stanie syntetyzować z niską częstością dirybonukleotydy zarówno przy braku jak i w obecności DNA [17,44,45]. Z kolei długość łącznika pomiędzy domenami ZBD i RBD jest istotna dla wydajnej i prawidłowej syntezy starterów prymazy T7 [42]. Prawidłowy łącznik zbudowany jest z 16 reszt aminokwasowych. Skrócenie go o 10 reszt aminokwasowych uniemożliwia syntezę dinukleotydów pppAC, ale umożliwia wydłużanie już istniejących dinukleotydów z wysoką wydajnością. Wydłużenie tego łącznika do 21 reszt aminokwasowych pozwala na syntezę pppAC i wydłużanie do tetrarybonukleotydu, ale ze znacznie niższą wydajnością. Nie tylko długość łącznika wpływa na wydajną syntezę startera, ale także wzajemne położenie względem siebie dwóch domen ZBD i RPD. Domeny ZBD i RBD oddziałują ze sobą w konformacji in cis, czyli obie domeny znajdują się na tym samym polipeptydzie, ale mogą także oddziaływać ze sobą in trans tzn. domena ZBD jednej prymazy oddziałuje $\mathrm{z}$ domena RPD drugiej prymazy. W przypadku oddziaływania obu domen in cis synteza startera jest wydajna. Natomiast w przypadku oddziaływania domeny ZBD i RPD in trans, wydłużanie powstałego dinukleotydu jest mniej wydajne, co związane jest z limitowaną długością linkera łączącego obie domeny [42]. Autorzy pracy [42] zwracają uwagę, że takie oddziaływania in trans może mieć miejsce w czasie syntezy DNA in vivo. Heksamer gp4 jest prawdopodobnie zbudowany z formy pełnej białka gp4 63 kDa i krótszej 56 kDa. Jeżeli obie formy znajdują się w heksamerze białka gp4, część syntezy tetranukleotydów może zachodzić in trans z udziałem domeny ZBD normalnej formy gp4 i domeny RPD formy skróconej. Ponieważ z badań in vitro wynika, że taka konformacja jest mniej korzystna i startery syntetyzowane są wolniej może to wpływać także na szybkość rozplatania DNA przez helikazę i w ten sposób regulować koordynację syntezy nici opóźnionej i wiodącej [42].

Synteza starterów z udziałem prymazy DnaG badana była na modelu prymazy z Aquifex aeolicus i Escherichia coli [46]. Prymaza E. coli DnaG inicjuje syntezę startera RNA rozpoznając sekwencję 5'-CTG-3' oraz 5'-CAG-3'. In vitro białko DnaG z E. coli może syntetyzować startery o długości do 60 nukleotydów, natomiast in vivo długość starterów ograniczona jest od 8-12 nukleotydów [21]. O ile w przypadku prymazy faga T7 dla syntezy pełnej długości starterów konieczna była obecność obu domen ZBD i RPD, to dla prymazy DnaG z E. coli pokazano, że sama domena RPD może syntetyzować startery z niską wydajnością niezależnie czy w matrycy obecna jest sekwencja inicjująca, a także syntetyzuje startery dłuższe niż 10-15 nukleotydów. Obecność domeny ZBD przywraca normalną aktywność prymazy, rozpoznawanie właściwej sekwencji i syntezę odpowiedniej długości starterów [46].

Analizy struktur krystalograficznych i SAXS (ang. Small-angle X-ray scattering, pol. rozpraszania promieniowania rentgenowskiego pod małymi katami) fragmentów obejmujących zarówno domeny ZBD i RPD z A. aeolicus i $E$. coli wykazały, że prymazy bakteryjne mogą występować w dwóch konformacjach, przyjmując częściej występującą tzw. zwartą strukturę, w której zachowane w ewolucji reszty domeny ZBD są izolowane od miejsca aktywnego domeny RPD oraz formę bardziej rozciągniętą, gdzie obie domeny są od siebie oddalone [46]. W zwartej strukturze łącznik pomiędzy domenami jest krótszy i jak wykazały to badania z udziałem FRET, oddziaływania pomiędzy obiema domenami mogą zachodzić nie in cis, ale in trans. To znaczy, że domena ZBD jednej prymazy może wiązać hybryd starter/matryca z domeną RPD innej cząsteczki prymazy. Takie oddziaływania pomiędzy podjednostkami prymazy in trans umożliwiają prymazie wybór miejsca inicjacji na DNA i działanie jak molekularny hamulec, który ogranicza zarówno procesywność jak i długość startera [46]. Zaproponowano więc, że podobnie jak w przypadku prymazy T7, oddziaływanie in trans może regulować syntezę startera, a tym samym tworzenie fragmentu Okazaki, poprzez ułatwienie kontaktu pomiędzy wieloma prymazami fizycznie związanymi z pierścieniem helikazy [46].

Prymosom faga T4 rozpoznaje sekwencje 5'-GTT-3' i 5' GCT-3'. Jak w przypadku pozostałych prymaz $3^{\prime}-\mathrm{T}$ nie wchodzi w skład statera. Fag T4 syntetyzuje pentarybonukleotydowe startery 5'-pppACNNN-3' oraz 5'-pppGCNNN-3'. Przy braku helikazy sama prymaza może tworzyć dimery, jak również produkty dłuższe niż 5 nukleotydów [7]. Ponieważ nie jest ustalona stechiometria kompleksu helikazy i prymazy nie wiadomo, w jaki sposób zachodzą oddziaływania w prymosomie.

\section{PRZEKAZYWANIE STARTERA DO POLIMERAZY}

Startery syntetyzowane przez prymazy na nici opóźnionej muszą być przekazane do polimerazy i wykorzystane do syntezy fragmentów Okazaki. Mechanizm przekazywania startera do polimerazy najlepiej został poznany i opisany dla faga T7. Startery syntetyzowane przez prymazę faga T7 są krótkie i nie tworzą stabilnego hybrydu RNA/DNA, dlatego prymaza jest niezbędna do ich stabilizacji. Polimeraza z kolei sama nie jest w stanie wydłużać takich krótkich starterów. Badania pokazały, że związany z prymazą starter jest bezpośrednio przekazywany do polimerazy [33]. W replisomie faga T7 zachodzą liczne oddziaływania pomiędzy polimerazą DNA faga T7 gp5 w kompleksie z czynnikiem procesywności trx - gp5/trx, a białkiem gp4. Polimeraza faga T7 nie jest procesywnym enzymem. Jej procesywność bardzo wzrasta po połączeniu z czynnikiem procesywności tioredoksyną (trx) kodowaną przez komórki gospodarza E. coli. Zaobserwowano dwa miejsca wiązania się polimerazy faga T7 gp5/trx do C- końcowej domeny helikazy gp4. Jedno to eksponowany rejon zawierający szereg zasadowych reszt aminokwasowych niedaleko helisy $\mathrm{O}$ polimerazy faga $\mathrm{T}$, drugie to 
rejon wiązania do dwóch zasadowych pętli w domenie TBD [47]. Ostatnia struktura uzyskana z wykorzystaniem mikroskopii Cryo-EM replisomu faga T7 pokazała, że polimeraza nici opóźnionej gp5/trx ${ }_{\text {lag }}$ ma także rozległe kontakty z dwoma cząsteczkami prymazy poprzez domenę "palców" i domenę egzonukleazy [48]. Wiązanie się polimerazy do domeny helikazy nie ma wpływu na tworzenie się kompleksu prymaza/starter/polimeraza (ang. priming complex), natomiast domena helikazy jest niezbędna do stabilizacji takiego kompleksu poprzez zapewnienie wiązania do ssDNA [43]. Utworzony starter jest przekazywany do polimerazy T7. Wczesne badania sugerowały, że tylko domena ZBD odpowiedzialna jest za dostarczenie startera [11,49]. Późniejsze badania wykazały, że N-końcowa subdomena domeny RPD jest także istotna w przekazywaniu startera do domeny egzonukleazy. Utworzony kompleks starter-matryca jest stabilizowany przez N-końcową subdomenę, a następnie kompleks ten jest dostarczany w taki sposób, żeby 3' koniec startera był eksponowany i wiązany przez polimerazę. Ważną rolę w tym procesie odgrywa Trp69. Zmiana reszty tryptofanu na reszte lizyny powoduje zaburzenia w przekazywaniu startera [12]. W prawidłowym procesie syntezy startera i przekazywaniu go do polimerazy zaangażowane są obie domeny prymazy ZBD i RPD [43]. Dla stabilizacji kompleksu prymaza/starter ważne jest występowanie w matrycy, w sekwencji rozpoznawanej przez prymazę, kryptycznej reszty cytozyny. Okazało się, że obie domeny ZBD i RPD odgrywają ważną rolę $\mathrm{w}$ rozpoznawaniu tej reszty cytozyny i w stabilizowaniu kompleksu [43]. W polimerazie T7 istnieje pętla zbudowana $\mathrm{z} 4$ reszt aminokwasowych (reszty aminokwasowe 401-404), która znajduje się w rowku wiążącym DNA. Usunięcie tych czterech reszt aminokwasowych sprawia, że polimeraza T7 nie jest w stanie wydłużać krótkich tetranukleotydowych starterów [50]. Istotną rolę w stabilizacji kompleksu prymaza/starter odgrywają także białka wiążące jednoniciowe DNA (białka SSB). Białka SSB kodowane przez faga T7 (gp2.5) pełnią bardzo ważną funkcję w czasie koordynacji syntezy nici wiodącej i opóźnionej. In vitro pokazano, że przy braku białek SSB syntetyzowane fragmenty Okazaki były krótsze niż syntetyzowane w obecności białek gp2.5. Ponadto pokazano, że białka te stymulowały aktywność białka gp4 i gp5 i podwyższały wydajność syntezy oligorybonukleotydów [51].

Podobnie jak w przypadku faga T7, SSB z E. coli pełnią ważną funkcję w koordynacji syntezy nici opóźnionej i wiodącej. Białka SSB odpowiadają za prawidłowe umiejscowienie prymazy w widełkach replikacyjnych i koordynują syntezę starterów [52]. Podczas replikacji nici opóźnionej tworzenie kompleksu pomiędzy prymazą DnaG i białkiem SSB jest ważne dla kontaktu prymaza-polimeraza na nici opóźnionej DNA. Prymaza DnaG współzawodniczy z podjednostkę X polimerazy III o wiązanie białka SSB. Prymaza DnaG, która związana jest ze starterem/matrycą i białkami SSB usuwana jest z kompleksu starter-matryca przez podjednostkę X polimerazy III, która wiążąc się z białkami SSB destabilizuje prymazę i umożliwia jej dysocjację z kompleksu pozwalając tym samym na przekazanie startera do polimerazy [53].
Podobną rolę białka SSB pełnią w systemie replikacyjnym faga T4 [54]. Ostatnio otrzymano strukturę krystalograficzną domeny RPD prymazy DnaG z Mycobactrium tuberculosis (MtDnaG) w kompleksie z ssDNA związanym z dinukleotydem imitującym starter [55]. Porównanie tej struktury z wcześniej otrzymaną strukturą domeny RPD z Staphylococcus aureus w kompleksie z ATP [56] posłużyło do stworzenia modelu wiązania się bakteryjnego białka DnaG z matrycą/starterem i określenia położenia ssDNA oraz wiązania startera $\mathrm{w}$ centrum aktywnym prymazy. Nałożenie stworzonego modelu na otrzymaną ostatnio strukturę cryo-EM kompleksu replikacyjnego faga T7 [48] pokazało, że 5' koniec ssDNA matrycy, który opuszcza centrum aktywne prymazy, jest przekazywany do centrum aktywnego polimerazy zachowując właściwą polarność. Zaproponowano także model przekazania startera do centrum aktywnego polimerazy. Model ten zakłada podobnie jak model stworzony dla prymazy faga T7, że obie domeny ZBD i RPD biora udział w przekazywaniu startera do polimerazy. Uważa się, że oddziaływanie in trans pomiędzy domenami bakteryjnej prymazy DnaG jest oddziaływaniem dominującym. Domena ZBD bierze udział w rozpoznawaniu miejsca inicjacji, ale także odgrywa istotną rolę w stabilizacji startera w czasie przekazywania do domeny polimerazy. Zaproponowany przez Hou i wsp. [55] model przekazywania startera do domeny polimerazy zakłada bezpośredni kontakt prymazy i polimerazy. Inne modele zakładają, że utworzony starter najpierw wiązany jest przez kompleks ładujący czynnik procesywności i czynnik procesywności - klamrę $\beta$, a następnie polimeraza III wiążę się do tego kompleksu i podejmuje syntezę fragmentu Okazaki $[57,58]$.

Dla faga T4, chociaż jest to obok faga T7 najlepiej poznany system replikacyjny, nieznany jest mechanizm przekazywania startera do domeny polimerazy. Biorąc pod uwagę fakt, że prymaza gp61 tworzy kompleks z helikazą gp41 zaproponowano dwa mechanizmy. W jednym, prymosom gp41-gp61 syntetyzuje pentarybonukleotydowe startery, a powstały kompleks pppRNA-gp61 pozostaje związany z ssDNA i oddysocjowuje od helikazy, tzw. model oddysocjacjowania prymazy, polegający na rozmontowaniu prymosomu (ang. primosome disassembly model) [59]. Następnie, kompleks pppRNA starter/matryca stabilizowany jest przez czynnik procesywności, który ładowany jest w obecności białek gp44/62. Do takiego kompleksu rekrutowana jest polimeraza faga T4, białko gp43, która podejmuje syntezę nowego fragmentu Okazaki. Drugi model zakłada, że prymaza pozostaje związana na stałe z helikazą. Starter syntetyzowany jest $\mathrm{w}$ kompleksie prymosomu, gdzie rekrutowane są białka gp44/62 i gp45, a następnie polimeraza przejmuje syntezę DNA. W modelu tym w czasie syntezy startera tworzy się druga pętla ssDNA, powstająca na skutek działania helikazy tzw. model pętli (ang. looping model) $[57,58,60]$.

\section{MODEL REPLIKACJI DNA NA NICI OPÓŹNIONEJ}

Koordynacja replikacji na nici wiodącej i opóźnionej stawia wiele wyzwań. W 1983 roku Bruce Alberts i wsp. [61], którzy badali replikację DNA faga T4 zaobserwowali, że 


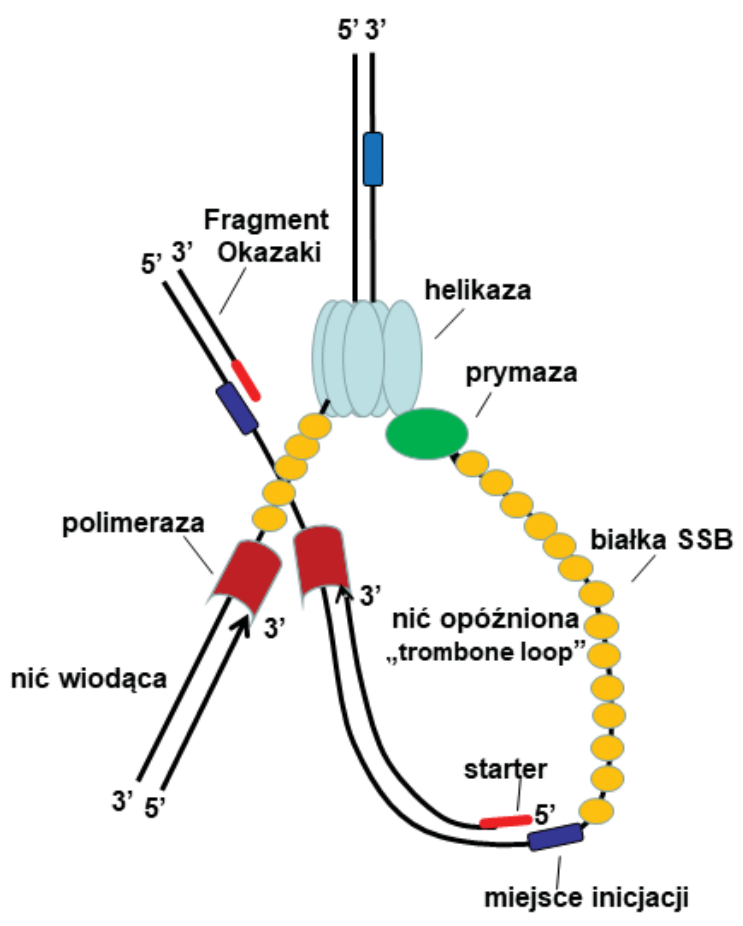

Rycina 2. Model replikacji - model „puzonu” (ang. trombone model). Nić wiodąca replikowana jest przez polimerazę w sposób ciągły natomiast nić opóźniona pokryta jest białkami SSB i replikowana jest w postaci fragmentów Okazaki. Skoordynowana replikacja nici wiodącej i opóźnionej możliwa jest po utworzeniu pętli "trombone loop"

raz związany z widełkami dimer polimerazy syntetyzuje jednocześnie replikację obu nici, wiodącej i opóźnionej. Ten model został później potwierdzony i pokazano, że raz związana polimeraza w widełkach replikacyjnych odpowiada za skoordynowaną syntezę całego genomu faga T4 [62,63]. W tym celu polimeraza nici opóźnionej musi oddysocjowywać i reasocjować w czasie syntezy każdego fragmentu Okazaki. Aby synteza obu nici w tym samym kierunku mogła się odbywać, zaproponowano model, w którym nić opóźniona jest wypętlona i zmienia swoją orientację, co pozwala na syntezę fragmentów Okazaki w tym samym kierunku co synteza nici wiodącej. Model ten porównano do puzonu (ang. trombone model), ponieważ wypętlona nić przypomina suwak puzonu (Ryc. 2). W czasie syntezy powstającego fragmentu Okazaki, podwójna nić DNA (dsDNA), będąca produktem syntezy nici opóźnionej i ssDNA, czyli produkt rozplatania DNA przez helikazę, prowadzą do powstawania pętli, która powiększa się do momentu rozpoczęcia syntezy następnego fragmentu Okazaki. Powstawanie tych pętli jest dynamiczne i przejściowe [64]. Tworzenie takich pętli nie tylko pozwala na syntezę obu nici $w$ tym samym kierunku, ale również umożliwia wielokrotne przyłączenie się polimerazy do nici opóźnionej w czasie syntezy (recykling polimerazy) $[62,63]$.

W systemie replikacyjnym faga T4 obecność replikacyjnych pętli zaobserwowano w mikroskopie elektronowym [64]. W czasie replikacji nici opóźnionej polimeraza DNA musi szybko wymieniać się w czasie syntezy każdego fragmentu Okazaki. Mechanizm, w jaki sposób polimeraza DNA jest dostarczana do nici opóźnionej nie jest do końca poznany. Założono, że musi istnieć jakiś sygnał, który powoduje, że polimeraza z trybu wysoce procesywnej syntezy DNA nagle oddysocjowuje od DNA, żeby następnie znowu zacząć syntezę kolejnego fragmentu Okazaki. Zaproponowano dwa modele, model kolizji (ang. colision model) i model sygnalizacji (ang. signaling model). W modelu kolizji, polimeraza zderza się z 5'-końcem DNA poprzedniego fragmentu Okazaki i oddysocjowuje, co prowadzi do powstania luki w DNA $[62,65,66]$.

W drugim modelu zaproponowano, że związanie startera RNA z czynnikiem procesywności w obecności kompleksu ładującego czynnik procesywności (białka gp45 i gp44/62 w replisomie faga T4) stanowi dla polimerazy sygnał do zakończenia toczącej się replikacji fragmentu Okazaki na nici opóźnionej [42]. Sygnałem dla polimerazy do oddysocjowania mogą też być związane z jednoczesną syntezą DNA na obu niciach negatywne torsyjne napięcia superhelikalnej struktury DNA [67], uwalnianie się pętli (ang. release of a priming loop) powstających $\mathrm{w}$ czasie rozplatania DNA przez helikazę i syntezy fragmentu Okazaki (ang. priming loop) [68], a także odkładanie się przed holoenzymem na nici opóźnionej kompleksów starter-prymaza, służących jako blokada na nici opóźnionej [69]. Po oddysocjowaniu polimeraza rekrutowana jest do kolejnego startera i następuje synteza kolejnego fragmentu Okazaki.

Dynamika oddziaływań w widełkach replikacyjnych może być bardziej złożona. Badania kompleksu replikacyjnego faga T4 jak i E. coli pokazały, że w obu przypadkach mechanizmy dające sygnał do oddysocjowania polimerazy mogą operować jednocześnie w czasie syntezy DNA na nici opóźnionej [58,70]. W jednej z prac [71] zaproponowano, że podczas replikacji w E. coli, równocześnie trzy polimerazy znajdują się $\mathrm{w}$ widełkach replikacyjnych. Jedna bierze udział w replikacji nici wiodącej, a dwie zaangażowane są w replikację nici opóźnionej.

Ostatnie badania prowadzone z użyciem techniki fluorescencyjnego znakowania i detekcji pojedynczej cząsteczki z użyciem mikroskopii fluorescencyjnej (ang. single-molecule fluorescence assay) pokazały, że dynamika oddziaływań w widełkach replikacyjnych jest inna niż dotychczas zakładano. Najnowsze prace pokazują, że polimerazy bakteryjne mogą łatwo wymieniać się w widełkach replikacyjnych i odbywa się to w sposób zależny od lokalnego stężenia polimerazy. Dodatkowo w badaniach tych wykazano, że synteza obu nici nie musi być skoordynowana i obie nici DNA mogą być replikowane niezależnie, a czynnikiem kontrolującym szybkość i koordynacje replikacji jest helikaza DnaB, która może zwalniać reakcję rozplatania DNA w momencie, kiedy polimeraza zwalnia proces replikacji $[70,72]$.

\section{PODSUMOWANIE}

Prymazy rodziny DnaG pełnią ważną funkcję w procesie replikacji DNA. Prymazy odpowiedzialne są za syntezę krótkich (5-12) oligorybonukleotydów RNA, które służą jako startery do inicjacji syntezy DNA na nici opóźnionej oraz w czasie inicjacji replikacji nici wiodącej. Prymazy zbudowane są z trzech domen: 
Domeny wiążącej cynk ZBD (ang. Zinc Binding Domain), której struktura podobna jest do struktury palców cynkowych. Chociaż rola tej domeny nie do końca została wyjaśniona to wydaje się, że pełni istotne funkcje $\mathrm{w}$ rozpoznawaniu specyficznych sekwencji DNA i wiązaniu się prymazy do DNA. Wykazano, że jest także potrzebna w procesie przekazywania startera do domeny polimerazy.

Domeny polimerazy RNA (RPD, ang. RNA Polymerase Domain), domeny katalitycznej w której dochodzi do syntezy najpierw krótkich dinukleotydów, które następnie są wydłużane do pełnej długości starterów. Budowa tej domeny przypomina budowę charakterystyczną dla topoizomeraz określaną, jako toprim. Obie domeny są konieczne dla wydajnej syntezy starterów.

Domeny C-końcowej, która nie pełni żadnej funkcji katalitycznej, ale jest niezbędna do oddziaływania prymazy z helikazą replikacyjną. Prymazy i helikazy w czasie replikacji tworzą kompleksy tzw. prymosomy, które odpowiadają za rozplatanie podwójnej nici DNA w celu udostępnienia jej polimerazom replikacyjnym oraz za syntezę krótkich oligoRNA starterów. Oba białka nawzajem stymulują swoją aktywność. Tworzenie prymosomu jest dynamiczne, dlatego też prymazy i helikazy często oddysocjowują i reasocjują $\mathrm{w}$ widełkach replikacyjnych. Niektóre prymazy bakteriofagowe, jak z bakteriofaga T7 i P4, występują jako dwufunkcyjne białka, tzn. prymazy i helikazy znajdując się na jednym polipeptydzie. Prymazy i helikazy replikacyjne są częścią bardziej złożonych kompleksow replikacyjnych, replisomów.

Prymazy bakteryjne różnią się budową i oddziaływaniami z białkami kompleksów replikacyjnych od polimeraz eukariotycznych. W dobie antybiotykooporności wielu szczepów bakteryjnych próbuje się znaleźć antybiotyki lub inne związki chemiczne, które wybiórczo hamowałyby aktywność prymaz bakteryjnych i prowadziły do zatrzymania replikacji DNA bakterii. Sposoby poszukiwania i różne podejścia do znalezienia skutecznych inhibitorów prymaz bakteryjnych zostały omówione w pracy przeglądowej [73]. Pomimo wielu prób jak do tej pory nie udało się znaleźć takiego związku, który znalazłby się $\mathrm{w}$ badaniach klinicznych, ale próby takie cały czas są podejmowane.

\section{PIŚMIENNICTWO}

1. Frick DN, Richardson C (2001) DNA Primases. Annu Rev Biochem 70: $39-80$

2. Heller RC, Marians KJ (2006) Replication fork reactivation downstream of a blocked nascent leading strand. Nature 439: 557-562

3. Iyer LM, Koonin EV, Leipe DD, Aravind L (2005) Origin and evolution of the archaeo-eukaryotic primase superfamily and related palm-domain proteins: structural insights and new members, Nucleic Acids Res. 33: 3875-3896

4. Kuchta R, Stengel G (2010) Mechanism and evolution of DNA primases. Biochim Biophys Acta 1804: 1180-1189

5. Pellegrini L, Costa A (2016) New insights into the mechanism of DNA duplication by the eukaryptic replisome. Trends Biochem Sci 10: 859871

6. Mitkova AV, Khopde SM, Biswas SB (2003) Mechanisms and stoichiometry of interaction of DnaG primase with DnaB helicase of E. coli in RNA primer synthesis. J Biol Chem 278: 52253-52261
7. Hinton DM, Nossal NG (1987) Bacteriophage T4 DNA primase-helicase. Characterization of oligomer synthesis by T4 61 protein alone and in conjunction with T4 41 protein. J Biol Chem 262: 10873-10878

8. Lee SJ, Richardson CC (2002) Interaction of adjacent primase domains within the hexameric gene 4 helicase-primase of bacteriophage T7. Proc Natl Acad Sci USA 99: 12703-12708

9. Flensburg J, Calendar R (1987) Bacteriophage P4 DNA replication. Nucleotide sequence of the $\mathrm{P} 4$ replication gene and the cis replication region. J Mol Biol 195: 439-445

10. Ilyina TV, Gorbalenya AE, Koonin EV (1992) Organization and evolution of bacterial and bacteriophage primase-helicase systems. J Mol Evol 34: 351-357

11. Kato M, Ito T, Wagner G, Richardson C, Ellenberger T (2003) Modular architecture of the bacteriophage T7 primase couples RNA primer synthesis to DNA synthesis. Mol. Cell 11: 1349-1360.

12. Zhu B, Lee S, Richardson C (2010) Direct role for the RNA polymerase domain of T7 primase in primer delivery. Proc Natl Acad Sci USA 107: 9099-9104

13. Mendelman LV, Beauchamp BB, Richardson CC (1994) Requirement for a zinc motif for template recognition by the bacteriophage $\mathrm{T} 7$ primase EMBO J13: 3909-3916.

14. Pan H, Wigley DB (2000) Structure of the zinc-binding domain of Bacillus stearothermophilus DNA primase. Structure 8: 231-239

15. Kato M, Ito T, Wagner G, Richardson CC, Ellenberger T (2003) Modular architecture of the bacteriophage T7 primase couples RNA primer synthesis to DNA synthesis. Mol Cell 11: 1349-1360

16. Krishna SS, Majumdar I, Grishin NV (2003) Structural classification of zinc Fingers: survey and summary. Nucleic Acids Res 3: 532-550

17. Akabayov B, Lee SJ, Akabayov SR, Rekhi S, Zhu B, Richardson CC (2009) DNA recognition by the DNA primase of bacteriophage T7: a structure-function study of the zinc-binding domain. Biochemistry 48: 1763-1773

18. Corn JE, Pelton JG, Berger JM (2006) Identification of a DNA primase template tracking site redefines the geometry of primer synthesis. Nat Struct Mol Biol 15: 163-169

19. Lee SJ, Zhu B, Akabayov B, Richardson Cc (2012) Zinc-binding domain of the bacteriophage T7 DNA primase modulates binding to the DNA template. J Biol Chem 287: 39030-39040

20. Larson MA, Griep MA, Bressani R, Chintakayala K, Soultanas P, Hinrichs SH (2010) Class-specific restrictions define primase interactions with DNA template and replicative helicase. Nucleic Acids Res 38 7167-7178

21. Keck JL, Roche DD, Lynch AS, Berger JM (2000) Structure of the RNA polymerase domain of $E$. coli primase. Science 287: 2482-2486

22. Podobnik M, McInerney P, O’Donnell M, Kuriyan J (2000) A TOPRIM domain in the crystal structure of the catalytic core of Escherichia coli primase confirms a structural link to DNA topoisomerases. J Mol Biol 300: 353-362

23. Aravind L, Leipe DD, Koonin E V (1998). Toprim- a conserved catalytic domain in type IA and II topoisomerases, DnaG-type primases, OLD family nucleases and RecR proteins. Nucl Acids Res 26: 42054213

24. Sun W, Schoneich J, Godson GN (1999) A mutant Escherichia coli primase defective in elongation of primer RNA chains. J Bacteriol 181: 3761-3767

25. Lee SJ, Richardson C C(2001) Essential lysine residues in the RNA Polymerase domain of the gene 4 primase-helicase of bacteriophage T7. J Biol Chem 276: 49419-49426

26. Godson GN, Schoenich J, Sun W, Mustaev AA (2000) Identification of the magnesium ion binding site in the catalytic center of Escherichia coli primase by iron cleavage. Biochemistry 39: 332-339

27. Su X, Schaeffer P, Loscha K, Gan P, Dixon N, Otting G (2006) Monomeric solution structure of the helicase binding domain of Escherichia coli DnaG primase. FEBS J 273: 4997-5009

28. Lu YB, Ratnakar PV, Mohanty BK, Batista D (1996) Direct physical interaction between DnaG primase and DnaB helicase of Escherichia coli 
is necessary for optimal synthesis of primer RNA. Proc Natl Acad Sci USA 93: 12902-12907

29. Naue N, Beerbaum M, Bogutzki A, Schmieder P, Curth U (2013) The helicase-binding domain of Escherichia coli DnaG primase interacts with the highly conserved C-terminal region of single-stranded DNA-binding protein. Nucleic Acids Res 41: 4507-4517

30. Corn JE, Berger JM (2006) Regulation of bacterial priming and daughter strand synthesis through helicase-primase interactions. Nucleic Acids Res 34: 4082-4088

31. Bird LE, Pan H, Soultanas P, Wigley DB (2000). Mapping protein-protein interactions within a stable complex of DNA primase and DnaB helicase from Bacillus stearothermophilus. Biochemistry 39: 171-182

32. Bailey S, Eliason WK, Steitz TA (2007) Structure of hexameric DnaB helicase and its complex with a domain of DnaG primase. Science 318: $459-463$

33. Wang G, Klein MG, Tokonzaba E, Zhang Y, Holden LG, Chen XS (2008) The structure of a DnaB-family replicative helicase and its interactions with primase. Nat Struct Mol Biol 15: 94-100

34. Johnson A, O’Donnell M (2005) Cellular DNA replicases: Components and dynamics at the replication fork. Annu Rev Biochem 74: 283-315

35. Ahnert P, Picha KM, Patel SS (2000) A ring-opening mechanism for DNA binding in the central channel of the T7 helicase-primase protein. EMBO J 19: 3418-3427

36. Norcum MT, Warrington JA, Spiering MM, Ishmael FT, Trakselis MA Benkovic SJ (2005) Architecture of the bacteriophage T4 primosome: electron microscopy studies of helicase (gp41) and primase (gp61). Proc Natl Acad Sci USA 102: 3623-3626

37. Satapathy AK, Kulczyk AW, Ghosh S, vanOijen AM Richardson CC (2011) Coupling dTTP hydrolysis with DNA unwinding by the DNA helicase of bacteriophage T7. J Biol Chem 286: 34468-34478

38. Bernstein JA, Richardson CC (1988) A 7-kDa region of the bacteriophage T7 gene 4 protein is required for primase but not for the helicase activity. Proc Natl Acad Sci USA 85: 396-400

39. Yang J, Xi J, Zhuang Z, Benkovic SJ (2005) The oligomeric T4 primase is the functional form during replication. J Biol Chem 280: 25416-25423

40. Jose D, Weitzel SE, Jing D, von Hippel PH (2012) Assembly and subunit stoichiometry of the functional helicase-primase (primosome) complex of bacteriophage T4. Proc Natl Acad Sci USA 109: 13596-13601

41. Toth EA, Li Y, Sawaya MR, Cheng Y, Ellenberger T (2003) The crystal structure of the bifunctional primase-helicase of bacteriophage T7. Mol Cell 12: 1113-1123

42. Qimron U, Lee SJ, Hamdan SM, Richardson CC (2006) Primer initiation and extension by T7 DNA primase. EMBO J 25: 2198-2208

43. Kulczyk AW, Richardson CC (2012) Molecular interactions in the priming complex of bacteriophage T7.Proc Natl Acad Sci USA 109: 94089413

44. Kusakabe T, Hine AV, Hyberts SG, Richardson CC (1999) The Cys4 zinc finger of bacteriophage T7 primase in sequence-specific single-stranded DNA recognition. Proc Natl Acad Sci USA 96: 4295-4300

45. Benkovic SJ, Valentine AM, Salinas F (2001) Replisome-mediated DNA replication. Annu Rev Biochem 70: 181-208

46. Corn JE, Pease PJ, Hura GL, Berger JM (2005) Crosstalk between primase subunits can act to regulate primer synthesis in trans. Mol Cell 20: 391-401

47. Loparo JJ, Kulczyk AW, Richardson CC, van Oijen AM (2011) Simultaneous single-molecule measurements of phage T7 replisome composition and function reveal the mechanism of polymerase exchange. Proc Natl Acad Sci USA 108: 3584-3589

48. Kulczyk AW, Moeller A, Meyer P, Sliz P, Richardson CC (2017) Cryo-EM structure of the replisome reveals multiple interactions coordinating DNA synthesis. Proc Natl Acad Sci USA 114: E1848-E1856

49. Kato M, Wagner T, Ellenberger T (2004) A molecular handoff between bacteriophage T7 DNA primase and T7 DNA polymerase initiates DNA synthesis. J Biol Chem 279: 30554-30562

50. Chowdhury K, Tabor S, Richardson CC (2000) A unique loop in the DNA-binding crevice of bacteriophage T7 DNA polymerase influences primer utilization. Proc Natl Acad Sci USA 97: 12469-12474
51. Lee J., Chastain PD Kusakabe T, Griffith JD, Richardson CC (1998) Coordinated leading and lagging strand DNA synthesis on a minicircular template. Mol Cell 1: 1001-1010

52. Sun W, Godson GN (1998) Structure of the Escherichia coli primase/ single-strand DNA-binding protein/phage G4oric complex required for primer RNA synthesis. J Mol Biol 276: 689-703

53. Yuzhakov A, Kelman Z, O’Donnell M (1999). Trading places on DNA - a three- point switch underlies primer handoff from primase to the replicative DNA polymerase. Cell 96: 153-163

54. Cha TA, Alberts BM (1990) Effects of the bacteriophage T4 gene 41 and gene 32 proteins on RNA primer synthesis: coupling of leading- and lagging-strand DNA synthesis at a replication fork. Biochemistry. 29: 1791-1798.

55. Hou C., Biswas T, Tsodikov OV. (2018) Structures of the catalytic domain of bacterial primase DnaG in complexes with DNA provide insight into key priming events. Biochemistry 57: 2084-2093

56. Rymer RU, Solorio FA, Tehranchi AK, Chu C, Corn JE, Keck JL, Wang JD, Berger JM (2012) Binding mechanism of metal NTP substrates and stringent-response alarmones to bacterial DnaG-type primases. Structure 20: 1478-1489

57. Manosas M, Spiering MM, Zhuang Z, Benkovic S, Croquette V (2009) Coupling DNA unwinding activity with primer synthesis in the bacteriophage T4 primosome. Nat Chem Biol 5: 904-912

58. Yao NY, Georgescu RE, Finkelstein J, O'Donnell ME (2009) Single-molecule analysis reveals that the lagging strand increases replisome processivity but slows replication fork progression Proc Natl Acad Sci USA 106: 13236-13241

59. Noble E, Spiering M, Benkovic S (2015) Coordinated DNA Replication by the Bacteriophage T4 Replisome. Viruses 7: 3186-3200

60. Benkovic SJ, Spiering MM (2017) Understanding DNA replication by the bacteriophage T4 Replisom. J Biol Chem 292: 18434-18442

61. Alberts BM, Barry J, Bedinger P, Formosa T, Jongeneel CV, Kreuzer KN (1983) Studies on DNA replication in bacteriophage T4 in vitro system. In Cold Spring Harb Symp Quant Biol: Cold Spring Harbor Laboratory Press: Cold Spring Harbor, NY, USA 47: 655-668

62. Kadyrov FA, Drake JW (2001) Conditional coupling of leading-strand and lagging-strand DNA synthesis at bacteriophage T4 replication forks. J Biol Chem 276: 29559-29566

63. Yang J, Nelson SW, Benkovic SJ (2006) The control mechanism for lagging strand polymerase recycling during bacteriophage T4 DNA replication. Mol. Cell 21: 153-164

64. Chastain PD 2nd, Makhov AM, Nossal NG, Griffith J (2003) Architecture of the replication complex and DNA loops at the fork generated by the bacteriophage T4 proteins. J Biol Chem 278: 21276-21285

65. Hacker KJ, Alberts BM (1994) The rapid dissociation of T4 DNA polymerase holoenzyme when stopped by a DNA hairpin helix. A model for polymerase release following the termination of each Okazaki fragment. J Biol Chem 269: 24221-24228

66. Carver TE., Sexton DJ, Benkovic SJ (1997) Dissociation of the bacteriophage 4 DNA polymerase and its processivity after completion of Okazaki fragment synthesis. Biochemistry 36: 14409-14417

67. Kurth I, Georgescu R, O'Donnell M (2013) A solution to release twisted DNA during chromosome replication by coupled DNA polymerases. Nature 496: 119-122

68. Nelson SW, Kumar R, Benkovic SJ (2008) RNA primer handoff in bacteriophage T4 DNA replication: the role of single-stranded DNA-binding protein and polymerase accessory proteins. J Biol Chem 283: 22838-22846

69. Spiering M, Hanoian P, Gannavaram S, Benkovic S (2017) RNA primer-primase complexes serve as the signal for polymerase recycling and Okazaki fragment initiation in T4 phage DNA replication. Proc Natl Acad Sci USA 114: 5635-5640

70. Graham JE, Marians JK, Kowalczykowski SC (2017) Independent and stochastic action of DNA polymerases in the replisome. Cell 169: 12011213 
71. Georgescu RE, Kurth I, O'Donnell ME (2011) Single-molecule studies reveal the function of a third polymerase in the replisome. Nat Struct Mol Biol 19: 113-116

72. Lewis JS, Spenkelink LM, Jergic S, Wood EA, Monachino E, Horan NP, Duderstadt KE, Cox MC, Robinson A, Dixon NE, van Oijen AM (2017) Single-molecule visualization of fast polymerase turnover in the bacterial replisome. eLife 6: e23932

73. Ilic S, Cohen S, Singh M, Tam B, Dayan A, Akabayov B (2018) DnaG Primase - a target for the development of novel antibacterial agents. Antibiotics (Basel) 7: 72
74. Rannou O, Le Chatelier E, Larson MA, Nouri H, Dalmais B, Laughton C, Jannière L, Soultanas P (2013) Functional interplay of DnaE polymerase, DnaG primase and DnaC helicase within a ternary complex, and primase to polymerase hand-off during lagging strand DNA replication in Bacillus subtilis. Nucleic Acids Research 41: 5303-5320

75. DeLano WL (2002) The PyMol molecular graphic system. DeLano Scientific, San Carlos, CA

\title{
Prokaryotic primases - structure and function
}

\section{Izabela Ziuzia-Graczyk ${ }^{1}$, Anna Bębenek ${ }^{2, \square}$}

${ }^{1}$ Department of Molecular Biology, Institute of Biochemistry and Biophysics, Polish Academy of Sciences, Warsaw, 5a Pawińskiego St., 02-106 Warsaw, Poland

${ }^{2}$ Laboratory of Mutagenesis and DNA Repair, Institute of Biochemistry and Biophysics, Polish Academy of Sciences, Warsaw, 5a Pawińskiego St., 02-106 Warsaw, Poland

$\square_{\text {e-mail: aniab@ibb.waw.pl }}$

Key words: primase, RNA polymerase, Toprim domain; helicase, SSB, replication fork.

\begin{abstract}
Primases are responsible for the synthesis of a short oligo RNA, which serves as primer for DNA polymerase. Primases play an essential role in the initiation of DNA replication at the origins, in the synthesis of Okazaki fragments and in the restart of stalled replication forks. Prokaryotic primases based on their structure and sequence alignments are classified as a family of DnaG proteins. Primases from this family contain three distinct domains: an amino terminal domain with a zinc ribbon motif involved in binding template DNA, a middle RNA polymerase domain, and a carboxyl-terminal region that either interacts with a helicase or is itself a DNA helicase. In this review, we are presenting the comparison of the representative primases from bacteria and bacteriophages, their mode of action and their involvement in DNA replication at the replication fork.
\end{abstract}

